\title{
DA LINGUAGEM DE HELENA SILVEIRA E DE SUA VISÃO SOBRE A LINGUAGEM TELEVISIVA
}

\author{
Hudinilson Urbano*
}

O presente trabalho pretende retomar, sob novos enfoques, a análise feita para o Projeto NURC (Projeto de Estudo da Norma Lingüística Urbana Culta) em textos (falado e escrito) de Helena Silveira, conceituada jornalista da Folha de S. Paulo nas décadas de 40 a 80, tendo atuado inicialmente como cronista social, especializando-se depois, nas últimas décadas, como crítica de telenovelas.

A referida análise abordou, sob o aspecto de seu planejamento textual (planejamento prévio, planejamento local) ${ }^{1}$, os discursos em questão, produzidos em 1976. Além dessa análise, tivemos antes a oportunidade de utilizar, em outro artigo, o mesmo discurso falado da jornalista, com o objetivo de exemplificar os recursos de "expressividade" que a língua falada particularmente produz e revela².

No presente trabalho, buscaremos, de um lado, observar algumas características estilísticas da linguagem da cronista em ambos os tipos de discurso e, por outro, destacar sua preocupação com a linguagem televisiva emergente (verbal e não verbal). Embora não se vise particularmente ao aspecto da contribuição da jornalista para a história da telenovela brasileira, não se pode deixar de destacar, na esteira de outros estudos já feitos, que ela, como crítica, não teve substituto nesse tipo de crônicas nos

* USP.

PRETI, D. (org.). Variedades de planejamento no texto falado e no escrito. In: Estudos de Língua Falada: variações e confrontos. São Paulo: Humanitas, 1998, p.131-151.

PRETI, D. (org.). A expressividade na língua falada de pessoas cultas. In: $O$ discurso oral culto. São Paulo: Humanitas, 1997, p. 91-110. 
URBANO, Hudinilson. Da linguagem de Helena Silveira e de sua visão sobre a linguagem televisiva.

jornais. Com efeito, com o fim de suas crônicas, "encerra-se o papel desse crítico personalizado, individual e cotidiano que foi Helena Silveira. Eé nesse sentido que podemos considerá-la como um fenômeno típico do alvorecer da telenovela no Brasil." 3 .

Na realidade, pretendemos cotejar seu depoimento, feito para o Projeto NURC em abril de 1976, com cerca de trinta crônicas e pronunciamentos publicados nas suas colunas no referido jornal, sobretudo em março e abril do mesmo ano, a saber: "Helena Silveira Vê TV"e "Videonário", nesta incluindo-se algumas seções de "Cartas na mesa".

Nesses textos, Helena Silveira escrevia pequenas crônicas sobre TV, fundamentalmente sobre telenovelas, reportava-se criticamente a capítulos em andamento e respondia, comentando, correspondências de seus leitores, que freqüentemente também faziam ponderações, de certa forma compartilhando posições críticas com a jornalista.

Sua linguagem jornalística de cronista televisiva é desmistificada e coloquial, interagindo facilmente com seus leitores em geral e com os signatários das cartas em particular, dominando um estilo leve, entre o moderado e simples, que ela parece ter criado especialmente para seus textos de jornal, temperados com uma cuidada dose de oralidade funcional e premeditada.

Havia em Helena Silveira uma preocupação particular com a coerência e verossimilhança, inclusive e sobretudo, com a linguagem televisiva, não só no aspecto verbal, como também no seu aspecto não verbal. Com efeito, surgindo a telenovela "como uma criação híbrida que integra o folhetim impresso, a radionovela, o teatro e o cinema" e tendo Helena Silveira uma "profunda bagagem literária e artística", buscava, de um lado, "entender a telenovela através de seu texto" e, de outro, se aperceber da importância da "imagem" na expressão televisiva. Nessas condições, ao valorizar criticamente a linguagem das telenovelas, Helena Silveira a contrapunha por vezes à linguagem do teatro e mesmo do rádio e do cinema.

Nosso enfoque será sobretudo sobre aos aspectos da linguagem (em particular verbal) em relação à busca do natural nas telenovelas e à necessidade de adaptação coerente da linguagem verbal às variedades lingüísticas relacionadas com as diversidades temporais e regionais, pontos de vista que Helena Silveira constantemente abordava.

No depoimento para o NURC/SP, ocorrido em plena época de seu mister na Folha, como comentarista de telenovelas, vários assuntos, programas e artistas nele

3 CostA, M. C. C. Como Helena Silveira vê TV. Arte e Cultura da América Latina. São Paulo: CESA, 1990, p.109-120. 
mencionados encontram eco nos textos do jornal. Preciosas críticas e informações são trazidas à baila, recebendo em ambas as situações comentários semelhantes, a atestar sua preocupação profissional e social sobre certos temas.

Uma das telenovelas que receberam destaque no seu depoimento e nas suas crônicas foi a telenovela $\mathrm{O}$ Bem Amado. Apenas para ilustrar a motivação do nosso estudo e dar uma idéia da dimensão e orientação de seus pronunciamentos, destacamos dois pequenos trechos da informante e escritora: o primeiro no texto falado:

“(...) não sei se vocês estão lembradas daquele jargão do Odorico Paraguaçu... que falava 'apenasmente'... éh 'a moribundice dele' 'a mo/' ((rindo)) ( ) eu me lem/ ((rindo)) eu imagino como será isso traduzido em castelhano né?... porque ele tinha peculiaridades de linguagem engraçadíssimas né?"

(linhas 473-78).

e, segundo, em uma de suas crônicas:

"O cabelo pintado, a fala cheia de neologismos de um pitoresco incomum, Odorico já se projeta fora do vídeo com uma vida suplementar, pessoas querendo imitá-lo no 'apenasmente', 'aliasmente', 'passeando sua defuntice', etc."

("Helena Silveira Vê TV", 18 fev. 1973)

A par desses comentários de ordem lingüística, Helena Silveira deixa registrado, tanto no depoimento quanto nas crônicas, fatos de interesse para a própria história e valorização da telenovela brasileira:

“(...) e por falar nisso... eu dei essa notícia ontem não sei se você sabe... que $O$ Bem Amado... traduzido para o espanhol El Bien Amado... está percorrendo toda a América Latina... está sendo um sucesso... enorme"

(linhas 461-65).

"El Bien Amado foi dublado no México e os uruguaios parecem satisfeitos com a parlapatice (será traduzível?) de Odorico Paraguaçu."

("Videonário", 6 abr. 1976)

Como se vê pela pequena amostra, Helena Silveira, pelas características do seu estilo de linguagem e pelo valor de sua contribuição para o conhecimento da televisão brasileira nos seu albores, merece e vale a pena ser referida e analisada por aqueles que se dedicam aos estudos da linguagem e das artes na mídia. 